ks. Grzegorz Godawa

Uniwersytet Papieski Jana Pawła II w Krakowie

\title{
Pedagogiczne aspekty duszpasterskiej działalności bł. ks. Władysława Bukowińskiego
}

11 września 2016 roku w Karagandzie odbyła się beatyfikacja ks. Władysława Bukowińskiego (1904-1974). Jego kapłańskie życie było ściśle związane z obszarem ówczesnego zSRR, dokąd trafił jako zesłaniec w czerwcu 1945 roku. Został oskarżony o zdradę władzy radzieckiej na rzecz Watykanu oraz o działalność duszpasterską i skazany na 10 lat karnych obozów pracy'. Zesłany na Wschód, pozostał tam do swojej śmierci, gdyż po odbyciu kary dobrowolnie postanowił nie opuszczać Związku Radzieckiego, chcąc nadal pełnić posługę wobec wiernych pozbawionych opieki duszpasterskiej. Za swoją nieugiętą postawę w 1959 roku został ponownie skazany na pobyt w obozie pracy. Ze swego prawie trzydziestoletniego pobytu w ZSRR ks. Bukowiński spędził w obozach i więzieniach łącznie ponad 13 lat². Jednak to nie długość osadzenia była powodem ogłoszenia ks. Władysława błogosławionym. Stała się nim postawa kapłana, który jako skazaniec, a potem obywatel komunistycznego państwa okazał się heroicznym głosicielem prawdy o Bogu.

Postać ks. Władysława zwraca uwagę na zasadnicze wartości kształtujące jego postawę wobec drugiego człowieka oraz niezwykłe zaangażowanie w ich realizację. Na temat teologicznego wymiaru jego działalności w ostatnim czasie ukazuje się coraz więcej publikacji, głównie dzięki naukowej i popularyzatorskiej działalności ks. Jana Nowaka, wicepostulatora procesu beatyfikacyjnego,

1 Por. J. Nowak, Niezłomny Pasterz. Duszpasterstwo ks. Władysława Bukowińskiego $w$ Kazachstanie $w$ latach 1950-1974, Kraków 2013, s. 97.

2 Por. tamże, s. 102. 
oraz innych ${ }^{3}$. Warto zauważyć, że wśród opracowań nie pojawił się, przynajmniej w sposób wyraźnie wyodrębniony, wątek pedagogicznej działalności ks. Bukowińskiego, a wydaje się on istotny. Założenie, że duszpasterstwo i wychowanie są ze sobą ściśle związane, wydaje się w pełni zasadne $e^{4}$, co uprawomocnia podjęcie poszukiwań na temat praktycznej realizacji wątków pedagogicznych w specyficznej działalności duszpasterskiej apostoła Kazachstanu. Wydaje się, że obecność tego wątku jest na tyle wyraźna, iż można podjąć próbę charakterystyki pedagogicznego rysu działalności prowadzonej przez błogosławionego. Jest ona, jak się wydaje, w dużej mierze skoncentrowana wokół wychowania. W tym celu niezbędne jest podjęcie próby zaprezentowania niektórych założeń procesu wychowania, które staną się kluczem do analizy czynów i słów ks. Władysława.

\section{Wychowanie w kontekście spotkania i dialogu}

Rzeczywistość wychowawcza jest na tyle złożona, że bardzo trudno podać jedną definicję wychowania, która spełniałaby oczekiwania logiczno-metodologiczne,

3 Analiza publikacji pozwala na wyodrębnienie następujących tekstów pisanych przez ks. Bukowińskiego: W. Bukowiński, Historia nauczycielka życia (Historia Polski pisana w łagrze), Kraków 2007; W. Bukowiński, Listy, red. J. Nowak, Kraków 2007; W. Bukowiński, Wspomnienia z Kazachstanu, Warszawa 2016; W. Bukowiński, Wybór wspomnień i informacji dla moich przyjaciót, red. J. Nowak, Kraków 2007.

Spośród opracowań warto wymienić: D. Lenik, Ze Wschodu na Zachód... Ewangeliczne drogi ks. W. Bukowińskiego. Refleksje dla cierpiacych i zagubionych oraz zdrowych i szczęśliwych. Droga Krzyżowa, Bielsko-Biała 2007; Dla moich przyjaciół. Wyjątki ze „Wspomnień", „Historii Polski"i „Listów" Stugi Bożego ks. Władysława Bukowińskiego, red. J. Nowak, Kraków 2008; J. Nowak, Apostoł Kazachstanu. Sługa Boży ks. Władysław Bukowiński (1904-1974), Kraków 2006; J. Nowak, Misjonarz Wschodu sługa Boży ks. Władysław Bukowiński, Kraków 2008; J. Nowak, Najbliżsi przyjaciele ks. Władysława Bukowińskiego - ks. Bronisław Drzepecki i ks. Józef Kuczyński, Kraków 2009; J. Nowak, Nie dałem się nigdy zatruć nienawiścią... Życie ks. Władysława Bukowińskiego $w$ świetle cnót chrześcijańskich ( $w$ perspektywie procesu beatyfikacyjnego), Kraków 2016; J. Nowak, Niezłomny Pasterz..., dz. cyt.; J. Nowak, Świadek. Życie i działalność sługi Bożego ks. Władysława Bukowińskiego, apostoła Kazachstanu, Kraków 2009; J. Nowak, Vianney Wschodu. Ks. Władysław Bukowiński, Kraków 2010; Sługa Boży ks. Władysław Bukowiński (1904-1974). Materiały z sympozjum zorganizowanego w Sanktuarium Bożego Miłosierdzia w Krakowie-Lagiewnikach 23 czerwca 2007 roku w pierwsza rocznicę rozpoczęcia procesu kanonizacyjnego, red. J. Nowak, Kraków 2007; Spotkałem człowieka. Ks. Władysław Bukowiński w pamięci wiernych i przyjaciół, cz. 1, red. W. J. Kowalów, Biały Dunajec-Ostróg 2001; Spotkałem człowieka. Ks. Władysław Bukowiński w pamięci wiernych i przyjaciót, cz. 2, red. W. J. Kowalów, Biały Dunajec-Ostróg 2006.

${ }_{4}$ Por. Jan Paweł II, List Juvenum patris w 10o. rocznicę śmierci św. Jana Bosko (31.01.1988), nr 17. 
a jednocześnie w sposób wyczerpujący opisywałaby proces wychowawczy. Wielość podejmowanych prób zdefiniowania wychowania świadczy więc o jego złożonej konstrukcji, a jednocześnie o wielkim zainteresowaniu zagadnieniem wychowania. W podziale zaproponowanym przez Andrzeja de Tchorzewskiego definicje wychowania można skategoryzować jako: sprawozdawcze, projektujące, regulujące oraz perswazyjne ${ }^{5}$. Sprawozdawczość w definiowaniu wychowania polega na próbie wiernego odtworzenia sensu tego pojęcia, zawartego w znaczeniu językowym. Przeciwne podejście zawierają w sobie definicje projektujące. Pośrednim ujęciem są definicje o charakterze regulującym, opisujące wychowanie, wykorzystując jego zastane znaczenie, a jednocześnie dokonując w nim koniecznych zmian. Z kolei definicje o charakterze perswazyjnym przedstawiają wychowanie w kontekście innych pojęć, dzięki czemu nabiera ono szerokich kontekstów społecznych ${ }^{6}$.

Inny podział definicji wychowania zaproponował Stefan Kunowski, który zwrócił uwagę na elementy występujące w tym zjawisku. Podział zawiera cztery różne podejścia: prakseologiczne, ewolucyjne, sytuacyjne oraz adaptacyjne ${ }^{7}$. Pierwsza kategoria definicji opiera się na założeniu, że wychowanie jest „urabianiem” osobowości wychowanka, najczęściej z pominięciem jego własnej aktywności. Definicje ewolucyjne upatrują w wychowaniu proces samorzutnego rozwoju wychowanka, w którym nabywa on potrzebnych doświadczeń. Podejście sytuacyjne zwraca uwagę na rolę, jaką w wychowaniu odgrywają sytuacje wychowawcze, natomiast podejście adaptacyjne podkreśla wymierne efekty wychowania, jakich oczekuje społeczeństwo ${ }^{8}$.

$\mathrm{Na}$ kanwie powyższych rozważań wyrasta wiele ujęć wychowania, a wśród nich wychowanie rozumiane jako spotkanie, będące szczególnym typem relacji z drugim człowiekiem. Jak zauważa Bogusław Śliwerski, w tym ujęciu wychowanie traktowane jest jako „całokształt procesów i oddziaływań zachodzących w toku wzajemnych relacji między dwiema osobami, a pomagającymi im urzeczywistniać i rozwijać swoje człowieczeństwo. Tak ujęte wychowanie jako spotkanie zakłada wzajemne uznanie i afirmację wolności. Dzięki niemu obie strony interakcji mogą ujawniać i urzeczywistniać wobec siebie wartości

5 Por. A. M. de Tchorzewski, Wychowanie, [w:] Encyklopedia pedagogiczna xxI wieku, t. 7, red. T. Pilch, Warszawa 2008, s. 318n.

6 Por. tamże, s. 318-320.

7 Por. S. Kunowski, Podstawy współczesnej pedagogiki, Warszawa 1996, s. 166-169.

8 Por. tamże. 
nadające sens ich życiu"' . Wychowanie podejmowane jako spotkanie jest więc interakcją dokonującą się w procesie, w toku spotkań, a jego zasadniczą kategorią jest dialog. Zakłada on podwójność i komplementarność ról: słuchania i mówienia, dawania i brania, wychowania i samowychowania ${ }^{10}$. W tym kontekście można przyjąć, że wychowanie jest spotkaniem i kontaktem człowieka mniej dojrzałego z dojrzalszym, podjętym $\mathrm{z}$ inicjatywy dojrzalszego ${ }^{11}$. Efektem tego spotkania jest rozwój osób biorących udział w nawiązanej interakcji.

Wychowanie jest działalnością charakteryzującą się cechami, które odróżniają ją od innych działań społecznych i uwiarygadniają podejmowane aktywności. Aby pokrótce zaprezentować katalog kryteriów wychowania, warto zwrócić uwagę na listę cech, którymi, według ks. Janusza Tarnowskiego, można opisać prawdziwe wychowanie. Autor wyprowadza je z założeń uprawianej prze siebie „pedagogiki dialogu” ${ }^{\text {12 }}$. Należą do nich ${ }^{13}$ :

- człowieczeństwo, które jest podstawowym odniesieniem każdego wychowania, gdyż jest ono spotkaniem co najmniej dwóch osób obdarzonych równą godnością, a jego celem jest pomoc każdemu w odnalezieniu i urzeczywistnieniu „najgłębszego ja”;

- permanencja, która oznacza, że procesu oddziaływań wychowawczych nie da się zmieścić w ciasnych ramach poszczególnych etapów dojrzałości człowieka, gdyż trwa on przez całe życie. Potrzeba opieki i wychowania, którą odczuwa dziecko, z biegiem czasu jest zaspokajana poprzez samowychowanie; - inter- i intraakcyjność, czyli obustronne oddziaływanie na siebie uczestników wychowania. W toku jego rozwoju wychowawca oddziałuje na wychowanka, a wychowanek na wychowawcę. Pomiędzy dwoma podmiotami wychowania zachodzi układ wzajemnych oddziaływań, który winna cechować współpraca i wzajemność ${ }^{14}$. Następuje także wchodzenie w akcję z samym sobą, czyli samowychowanie;

- nieokreśloność, dotycząca zdarzeń i ich konsekwencji dla procesu wychowawczego. Z tego względu wychowawcy muszą zachować elementarną świeżość oceny sytuacji oraz nieustannie otwierać się na nowości, które przynosi

9 B. Śliwerski, Pedagogika ogólna. Podstawowe prawidłowości, Kraków 2012, s. 199.

10 Por. tamże, s. 200.

${ }^{11}$ Por. E. Sujak, Życie jako zadanie, Warszawa 1978, s. 119.

12 Por. M. Nowak, Dialog w wychowaniu, „Pedagogia Christiana” 25 (2010), s. 86.

13 Por. B. Śliwerski, Współczesne teorie i nurty wychowania, Kraków 2015, s. 78.

14 Por. M. Łobocki, Teoria wychowania w zarysie, Kraków 2006, s. 53. 
codzienne życie, przy równoczesnym zachowaniu równowagi, ugruntowaniu swojej wiedzy i systemu wartości;

- transgresyjność, czyli zdolność przekraczania swoich trudności, ograniczeń samego siebie. Transgresyjny charakter wychowania napawa więc nadzieją, ale jednocześnie domaga się stosowania takich form oddziaływań wychowawczych, które będą pomagały wychowankowi w pokonywaniu samego siebie.

Zaprezentowane właściwości wychowania powstały jako dorobek chrześcijańskiej pedagogiki personalno-egzystencjalnej. Wydaje się, że mogą one posłużyć do analizy postawy wychowawczej ks. Władysława Bukowińskiego, gdyż pedagogiczny rys jego posługi duszpasterskiej jest w dużym stopniu adekwatny do jej założeń, choć wspomniana koncepcja wychowania prawdopodobnie nie była mu znana, gdyż jej powstanie jest zbieżne z kresem życia ks. Władysława ${ }^{15}$. Analiza postawy i działań podejmowanych przez błogosławionego pozwoli na pogłębienie znajomości i rozumienia życia tego kapłana.

\section{Pedagogia ks. Władysława Bukowińskiego}

Podczas pobytu w Kazachstanie Jan Paweł II powiedział o ks. Bukowińskim: „Cieszę się, że postać tego bohaterskiego kapłana nie idzie w zapomnienie. Przeciwnie, pozostaje on w pamięci wielu jako heroiczny świadek Chrystusa"16. Słowa papieża wskazują na postawę błogosławionego, która w ekstremalnych warunkach życia była świadectwem głębokiej wiary, nadziei i czynnej miłości do Boga i bliźnich. Potwierdził tę prawdę papież Franciszek, który w dniu beatyfikacji po modlitwie Anioł Pański nawiązał do postaci nowego błogosławionego: „Ileż ten człowiek wycierpiał! W życiu zawsze okazywał wielką miłość dla najsłabszych i najbardziej potrzebujących, a jego świadectwo jawi się jako przeobfitość uczynków miłosierdzia względem duszy i względem ciała" ${ }^{\prime 17}$.

Analiza wybranych wątków działalności i wypowiedzi ks. Władysława w kontekście przytoczonych wcześniej kryteriów wychowania pozwoli na zarysowanie prezentowanej przez niego pedagogii. Heroizm miłości, o którym mówili

15 Por. J. Tarnawski, Problem chrześcijańskiej pedagogiki egzystencjalnej, „Collectanea Theologica” 44 (1974), s. 5-23.

16 J. Nowak, Świadek. Życie..., dz. cyt., s. 5.

17 Beatyfikacja ks. Bukowińskiego Apostoła Kazachstanu, http://pl.radiovaticana.va/news/2016/o9/11/ beatyfikacja_ks_bukowi\%C5\%84skiego_aposto\%C5\%82a_kazachstanu/1257363 (3.10.2016). 
papieże, znalazł odzwierciedlenie w wychowaniu - działalności ukierunkowanej na rozwój człowieka.

\section{Człowieczeństwo}

Człowieczeństwo i związana z nim godność osoby ludzkiej stanowi jedną $\mathrm{z}$ podstawowych wartości prezentowanych przez błogosławionego. Ksiądz Bukowiński dostrzegał godność człowieka, mimo że to zadanie było niekiedy bardzo utrudnione, zwłaszcza podczas pobytu w łagrach. Egzystowanie w ekstremalnych warunkach powodowało, że ludzie zatracali poczucie własnej wartości, a upokorzeni przez oprawców rezygnowali z walki o zachowanie ludzkiej godności. Postawa ks. Władysława była odmienna. Poprzez swoją działalność starał się przywrócić godność uciemiężonym zesłańcom, niezależnie od tego, jakiej religii czy orientacji umysłowej byli wyznawcami. Jeszcze przed zesłaniem ks. Bukowiński, jako proboszcz katedry w Łucku, troszczył się o zaspokojenie podstawowych potrzeb swoich parafian i wszystkich przychodzących po pomoc. W tym celu założono komitet pomocy biednym, w którego działalność bardzo silnie był zaangażowany ${ }^{18}$.

Podczas pobytu w łagrach starał się okazywać pomoc współwięźniom, co wymagało przezwyciężenia lęku o siebie i otwarcia się na innych. Ta pomoc dotyczyła prób zaspokojenia głodu współwięźniów, z którymi kapłan dzielił się własną porcją jedzenia ${ }^{19}$. Była to także troska o duchowy i religijny wzrost człowieka. W tym celu ks. Władysław podejmował działania, których wykrycie groziło śmiercią. Wykorzystywał przy tym szerokie wykształcenie, które zdobył podczas studiów na Uniwersytecie Jagiellońskim ${ }^{20}$. Tak wspomina te wydarzenia o. Grabski, jeden z jego współwięźniów w Dżezkazganie:

Dzielił się swą niezwykle szeroką wiedzą filozoficzną, teologiczną, historyczną czy literacką. Nie zapomnę wykładów na temat filozofii życia, historii Ojców Kościoła i patrystyki. Posługiwał się jedynie swą genialną pamięcią. Dla nas kapłanów była to akademia umiejętności. Było wielu miłośników historii Polski. I tu ks. Bukowiński okazał się wprost godnym podziwu. [...] Wokół siebie gromadził nie tylko Polaków. Bardzo chętnie słuchali go Niemcy, przeważnie wyżsi oficerowie; słuchali go innowiercy. I tu należy zwrócić uwagę, że ten kapłan Boży

\footnotetext{
18 Por. J. Nowak, Nie dałem się..., dz. cyt. s. 72.

19 Por. tamże, s. 73.

${ }_{20}$ Por. J. Nowak, Niezłomny Pasterz..., dz. cyt., s. 76-78.
} 
o wiele lat wyprzedził Sobór Watykański II. Kiedy tylko nadarzała się sposobność przemawiał do braci odłączonych, a słowom jego towarzyszyła jakaś siła i moc ${ }^{21}$.

Umiejętność duchowego wsparcia wynikała nie tylko z posiadanej wiedzy i kompetencji, ale była przede wszystkim owocem wiary i miłości kapłana. Czerpiąc siły do heroicznej postawy z modlitwy, zachęcał do niej i inicjował ją wśród więźniów, spowiadał, katechizował, odprawiał potajemnie msze św., a nawet w 1954 roku wygłosił rekolekcje $\mathrm{e}^{22}$. Co godne podkreślenia, ks. Władysław dostrzegał godność także w strażnikach więziennych, od których więźniowie doświadczali wiele zła. Błogosławiony starał się zauważyć każdy przejaw dobra $z$ ich strony, choć niekiedy wymagało to $z$ jego strony heroizmu ${ }^{23}$. Oddziaływanie duszpastersko-wychowawcze kapłana wyraźnie zmierzało do zachowania bądź ponownego odkrycia godności człowieka, niezależnie od jego pochodzenia i pełnionej roli.

\section{Permanencja}

Ksiądz Bukowiński był świadomy, że człowiek powinien rozwijać się przez całe życie. Wiedział, że pomoc w tym względzie mogą stanowić sakramenty, które towarzyszą człowiekowi w jego religijnym wzroście. Szafowanie sakramentów, obok głoszenia Słowa Bożego, stało się dla ks. Władysława zasadniczą posługą, którą pełnił po wyjściu z łagrów. Były one często sprawowane w okolicznościach, które odbiegały od standardowych. Już samo zagrożenie karami związanymi z prowadzeniem nielegalnej działalności duszpasterskiej powodowało, że spotkania modlitewne odbywały się w specyficznych miejscach i warunkach. Apostoł Kazachstanu tak opisuje swą dyskretną posługę w prywatnych domach swoich wiernych:

Zazwyczaj odbywa się to tak: przychodzę po południu lub przed wieczorem. [...] Następnie spowiadam. Mszę świętą odprawiam o godzinie 9 wieczorem, czasem i z opóźnieniem. Po Mszy świętej zwykle jeszcze spowiedź. Wreszcie krótki spoczynek nocny. Krótki, bo kładę się spać zwykle po północy, a już o godzinie wpół do 6 lub 6 rano jest poranna Msza święta, a potem dalej spowiedź, bywają chrzty i namaszczenia olejem świętym, bywają i śluby ${ }^{24}$.

\footnotetext{
${ }^{21}$ Spotkałem człowieka..., cz. 1, dz. cyt., s. 53.

${ }^{22}$ Por. J. Nowak, Niezłomny Pasterz..., dz. cyt., s. 124.

${ }_{23}$ Por. J. Nowak, Nie dałem się..., dz. cyt., s. 77.

${ }^{24}$ W. Bukowiński, Wspomnienia..., dz. cyt., s. 116.
} 
Warto podkreślić, iż zaangażowanie, z jakim ks. Władysław troszczył się o duchowy wzrost odwiedzanych przez siebie ludzi, było proporcjonalne do poziomu ich religijnych potrzeb, na spełnienie których oczekiwali niekiedy kilkadziesiąt lat ${ }^{25}$. Należy zaznaczyć, iż pedagogiczne umiejętności ks. Władysława uchroniły go od pobieżnego traktowania zadań, które przerastały jego możliwości. W swoich pismach podkreśla znaczenie przygotowania powierzonych sobie osób do przyjęcia sakramentów, a także odpowiedzialności za tę formację. To oznacza, że był świadomy konieczności sprostania wyzwaniu, jakim jest formowanie pełnych postaw religijnych, a więc także podnoszenie poziomu wiedzy religijno-moralnej, kształtowanie świadomości, emocji i czynów. Zasadniczo udzielenie każdego sakramentu było poprzedzone wypracowaną przez błogosławionego formułą przygotowania. Dużą rolę przywiązywał do kształtowania właściwych postaw rodzicielskich, które mogły przyczynić się do pogłębienia wiary w rodzinie ${ }^{26}$.

Zdając sobie sprawę z silnego wpływu ideologii wrogiej religii, starał się przygotować wiernych do zachowania wiary, w czym mieli pomagać sobie nawzajem członkowie rodziny. W tym kontekście można umiejscowić decyzję ks. Władysława o dobrowolnym pozostaniu w Związku Radzieckim po zakończeniu odbywania kary ${ }^{27}$. Wiedział, że jego obecność wśród ludzi pozbawionych jakiejkolwiek opieki duszpasterskiej będzie dla nich ważną pomocą i odniesieniem. Warto zwrócić uwagę, że w duszpasterstwie, które charakteryzowało się dużą okazjonalnością spotkań, ks. Władysław troszczył się, by wyznawcy Chrystusa rozwijali się w sposób nieustanny, aktywnie uczestnicząc w procesie duchowego wzrostu. Rzadkie, ale niezmiernie intensywnie przeżywane odwiedziny wśród wiernych umacniały ich w przekonaniu, że ich wiara jest ważna i należy jej rozwojowi poświęcić wiele wysiłku, niezależnie od posiadanego wieku.

\section{Interakcyjność}

Pedagogia ks. Bukowińskiego opierała się na relacji nawiązywanej z ludźmi, nad którymi sprawował opiekę. Chociaż styl duszpasterzowania bez kościoła nie sprzyjał nawiązywaniu pogłębionych więzi z wiernymi, kapłan starał się, by ich jakość była jak najlepsza. Przykładał dużą wagę do każdego spotkania, którego był uczestnikiem: „Bywa często tak, że jestem pierwszym księdzem

\footnotetext{
25 Por. tamże, s. 119.

26 Por. tamże, s. 135.

27 Por. J. Nowak, Vianney Wschodu..., dz. cyt., s. 29.
} 
katolickim, którego widzi w życiu osoba ze mną rozmawiająca, albo też pierwszym od 20, czy nawet 40 lat. Muszę zrobić wszystko, co leży w mojej mocy, by ta osoba odniosła jak najlepsze wrażenie ze spotkania z księdzem. Jeśli się taka osoba spowiada, to nie wolno jej zbywać, oglądać się na zegarek, lecz trzeba jej pozwolić całkowicie wypowiedzieć się"28.

Pieczołowicie budowane relacje stanowiły dla błogosławionego fundament skutecznych interakcji wychowawczych. Świadectwa osób, które osobiście znały ks. Władysława, są nasycone dużą sympatią i życzliwością wobec niego. Świadczy o niej także fakt, że na pogrzeb błogosławionego przybyły rzesze wiernych wdzięcznych za jego posługę ${ }^{29}$.

Ważnym aspektem wychowawczego oddziaływania ks. Bukowińskiego były listy, które pisał do swoich znajomych i przyjaciół, zwłaszcza w Polsce. Lektura zachowanych listów utwierdza w przekonaniu, że więzi międzyosobowe były dla tego kapłana bardzo ważne. Wieloletnie podtrzymywanie ich za pomocą korespondencji, mimo rzadkich odwiedzin, skutkowało dogłębnym zainteresowaniem oraz znajomością treści codziennego życia każdej z rodzin i poszczególnych przyjaciół. Tylko w niewielkim stopniu chroniło to ks. Władysława przed bolesną samotnością, której nadawał znaczenie poprzez odniesienie do podejmowanych działań. Pisał w jednym z listów: „Miara mojego osamotnienia jest miarą mojej społecznej użyteczności”30.

Interakcje nawiązywane z wiernymi wpływały na osobowośćks. Władysława. Także spotkania z osobami reprezentującymi odmienny światopogląd wzbudzały w nim refleksje. Dzięki otwarciu na te osoby oddziaływanie wychowawcze ks. Bukowińskiego było skuteczniejsze. Szczególnie ważny dla niego był kontakt z młodymi ludźmi. Zarówno w łagrze, jak i w Karagandzie ks. Władysław:

słuchał tego, co mieli do powiedzenia i wykazywał zainteresowanie ich życiem. Z ogromną umiejętnością i życzliwością udzielał im wskazówek, umacniał w wierze, zachęcał do pracy nad sobą, do rozwoju zainteresowań i zdobywania wiedzy. W czasie długich podróży misyjnych trwających po kilka miesięcy często nadarzała się okazja do rozmowy z młodymi niewierzącymi ludźmi. Podobnie było w obozach pracy. Często takie rozmowy kończyły się nawróceniem i przyjęciem przez rozmówców sakramentów ${ }^{31}$.

\footnotetext{
${ }_{28}$ W. Bukowiński, Wspomnienia..., dz. cyt., s. 122.

29 Por. J. Nowak, Vianney Wschodu..., dz. cyt., s. 28n.

30 W. Bukowiński, Listy, dz. cyt., s. 85.

${ }^{31}$ J. Nowak, Nie dałem się..., dz. cyt., s. 78.
} 
Umiejętność stanięcia na jednym poziomie ze spotkanym człowiekiem skutkowała wzajemnym otwarciem, nawróceniami, a także inspirowała ks. Władysława do wysiłku zachowania świeżości spojrzenia na drugiego człowieka.

\section{Intraakcyjność}

Ksiądz Bukowiński, troszcząc się o rozwój swoich „parafian”, dbał jednocześnie o własny rozwój. Krytyczna refleksja nad sobą nie zawsze była łatwa do zaakceptowania, jednak dzięki niej w nastawieniu ks. Władysława do innych było dużo pokory i łagodności. Wypływały one ze znajomości samego siebie, swoich słabości i ograniczeń. Świadectwem tego mogą być słowa zaczerpnięte $\mathrm{z}$ jednego z listów błogosławionego: „Delikatnie mówić - jestem za mało pobożny. Co gorsza, nie odczuwam zapału do pobożności, raczej zmęczenie, nieraz przemęczenie. Nie chcę dopuścić do upadku ducha, ale nieraz mam wyrzuty sumienia, że nazbyt wygodnie, bez należytego wysiłku poczynam sobie na starość..." ${ }^{32}$. Świadomość potrzeby nieustannego duchowego wysiłku, także w podeszłym wieku, mobilizowała kapłana do pokonywania własnych ograniczeń i przeciwdziałania apatii. Zmagając się z chorobami i konsekwencjami starości, nie poddawał się znużeniu, posługując na miarę swoich sił do ostatnich dni życia.

Szczera ocena samego siebie stanowiła ważny element jego wewnętrznego rozwoju, na który składała się cała mozaika czynników wewnętrznych i zewnętrznych. Samowychowanie, które stanowiło dla ks. Władysława element rozwoju religijnego, było wyznaczone przez osobiste praktyki religijne, ascezę, nawrócenie. Pomimo odczuwanych słabości, jego wiara i miłość wzrastały, chociaż istniało wiele czynników temu przeciwnych. W środowisku przemocy i zła jego wewnętrzne usposobienie było pełne pokoju i zaufania Bożej Opatrzności. To właśnie ona stanowiła dla kapłana najważniejsze odniesienie i źródło siły.

\section{Nieokreśloność}

Od samego początku pobytu ks. Władysława na Wschodzie towarzyszyły mu okoliczności, które pozbawiały poczucia stabilizacji i przynosiły kolejne wyzwania. Sam wspomina w jednym z listów: „Kiedy przed 17 laty zostałem skierowany do Karagandy, to nie powiem, żeby pierwsze wrażenia były dodatnie i zachęcające na przyszłość. A jednak już po tygodniu wiedziałem, że to jest ogromne, wówczas nietknięte pole do pracy, i że powinienem tu pozostać

\footnotetext{
${ }_{32}$ W. Bukowiński, Listy, dz. cyt., s. 167.
} 
możliwie jak najdłużej"33. Chcąc podjąć to wyzwanie, ks. Władysław musiał nauczyć się umiejętności akomodacji do zmieniających się warunków. Tę umiejętność wykorzystywał m.in. w celu wsparcia powierzonych mu osób, zarówno w łagrach, jak i podczas odwiedzania rodzin. Zmieniające się warunki wymagały od ks. Bukowińskiego elastyczności, a jednocześnie weryfikowały jego wartości, konsekwencję i wierność. Każdy okres życia ks. Władysława uczył go otwartości na różne formy działalności duszpasterskiej. Ta pełna nadziei nowość była głęboko zakorzeniona w świadomości tego, kim jest i jakie są jego zadania ${ }^{34}$.

Obszarami pracy duszpasterskiej, w których niezbędne było dostosowanie form i metod oddziaływania, były: liturgia, głoszenie Słowa Bożego i katecheza. Chcąc być zrozumianym przez wszystkich, ks. Władysław wykorzystywał swoje zdolności językowe, przez co docierał do ludzi różnych narodowości ${ }^{35}$. Dostosowywał także treści nauczania do potrzeb słuchaczy, dbając jednak o zachowanie zasadniczego trzonu. Opracował własny, skrócony program przygotowania do sakramentów, który realizował w zależności od zmieniających się okoliczności. Metody pracy katechetycznej realizowane przez błogosławionego były na tyle elastyczne, że utarte schematy nie przysłaniały aktualnych potrzeb spotykanych ludzi.

Ksiądz Władysław Bukowiński, mimo iż funkcjonował w niezwykle trudnych i dynamicznie zmieniających się warunkach, nie zatracił poczucia swej tożsamości kapłana i Polaka. Jego postawa była świadectwem niezłomności oraz wierności Bogu i drugiemu człowiekowi.

\section{Transgresyjność}

Przekraczanie samego siebie i umiejętność wdrażania do takiej postawy stanowią ukoronowanie działań wychowawczych. Przed ks. Bukowińskim pojawiało się wiele trudności, które starał się pokonać, zawsze zdając się „na Opatrzność z całą nigdy niezawodną ufnością"36.

Wiele wysiłku kosztowało go zmaganie się z niszczącym wpływem systemu komunistycznego, który przeciwstawiał się jego działalności. Wrogie nastawienie wobec wszelkich przejawów religijności dotykało kapłana w sposób szczególnie bolesny. Jednak nienawiść nie zniszczyła ks. Władysława. Współpraca

\footnotetext{
33 Tamże, s. 275.

34 Por. J. Nowak, Niezłomny Pasterz..., dz. cyt., s. 281.

35 Por. tamże, s. 201.

${ }_{36}$ W. Bukowiński, Listy, dz. cyt., s. 406.
} 
z Bożą łaską zaowocowała stanem ducha, który błogosławiony opisał następującymi słowami: „Zdaje się, że nie dałem się nigdy zatruć nienawiścią i że miłość nieprzyjaciół nie była tylko piękną teorią w mym życiu na Wschodzie"37. Wzniesienie się ponad zło było owocem współpracy ks. Władysława z łaską Bożą oraz pracy nad sobą.

Wydaje się, że to oddziaływanie posiadało szczególną skuteczność i stawało się wzorem do naśladowania, o czym zaświadcza wypowiedź więźnia ks. Eliasza Głowackiego:

W tym piekle zła, niesprawiedliwości, krzywdy, bólu i cierpienia szukałem człowieka - wzoru dla siebie. Tym wzorem człowieka i kapłana był dla mnie przez 9 lat w łagrach i pozostanie na zawsze tutaj obecny ksiądz Władysław Bukowiński. [...] Kiedy go bliżej poznałem, starałem się naśladować. Kontakty z nim podtrzymywały mnie na duchu, zrozumiałem wartość cierpienia, dzięki czemu nie załamałem się - owszem wzrosła we mnie wiara i nadzieja lepszego jutra ${ }^{38}$.

Błogosławiony dawał swym życiem przykład, który inspirował i skłaniał do naśladowania. Co najważniejsze, skutki tego naśladowania objawiały się poprzez duchowy i osobowościowy wzrost osób spotykających się z nim. Świadectwo zawierzenia Bożej Opatrzności oraz niepoddawania się otaczającemu zewsząd złu stanowiło przykład, który stał się najdojrzalszym sposobem oddziaływania wychowawczego.

\section{Zakończenie}

Ksiądz Władysław Bukowiński nie posiadał wykształcenia pedagogicznego, ale analiza jego działalności pozwala na dostrzeżenie pedagogicznego wymiaru jego pracy duszpasterskiej. Posiadała ona na tyle wyraźny i oryginalny rys, iż można mówić o pedagogii ks. Bukowińskiego. Powstała ona jako odpowiedź na potrzebę głoszenia prawd ewangelicznych w taki sposób, by wzmacniały rozwój człowieka we wszystkich obszarach jego życia. Jest to pedagogia chrystocentryczna, z wyraźnym odniesieniem do wartości, które wynikają z Ewangelii. Wśród nich zasadnicze miejsce zajmuje godność człowieka, marginalizowana przez system komunistyczny. Silne podstawy aksjologiczne tej pedagogii generowały zasady życia, które ks. Władysław uznawał i uczył

37 W. Bukowiński, Wspomnienia..., dz. cyt., s. 106.

${ }^{38}$ Spotkałem człowieka..., cz. 2, dz. cyt., s. 74 . 
zachowywać. Warto podkreślić, iż elastyczność w jego podejściu do wszelkich podejmowanych działań sprawiała, że nawet niezmienne i wymagające zasady potrafił tak ukazać, iż stawały się one łatwiej akceptowalne i możliwe do zastosowania.

Niewątpliwie ważnym czynnikiem oddziaływania wychowawczego ks. Władysława był autorytet. Kapłan był świadomy, że go posiada, i wiedział, że jest ważnym odniesieniem dla powierzonych sobie wiernych. Jednocześnie dbał o to, by postrzeganie go jako wzór nie przysłaniało centralnej postaci jego nauczania - Chrystusa. Pomagała mu w tym szczerość i krytyczne spojrzenie na samego siebie. Zarazem potrafił zachować postawę szacunku i wyrozumiałości dla ludzkich słabości.

Pedagogia ks. Władysława opierała się na kategorii spotkania. Całe jego duszpasterstwo było serią bezpośrednich spotkań z ludźmi w różnych okolicznościach i etapach ich życia. Posługując się metodą dialogu, docierał do wierzących w Chrystusa, wyznawców innych religii i ateistów. Otwarcie na drugiego człowieka pozwoliło mu na stworzenie kanałów komunikacyjnych, które stawały się kanałami łaski Bożej.

Pedagogia ks. Bukowińskiego była kreatywna i jednocześnie skuteczna. Obie te cechy były podporządkowane warunkom, $w$ jakich pracował. Chcąc ogarnąć pomocą jak największą liczbę wiernych, dostosowywał się do dostępnych mu możliwości głoszenia Ewangelii i sprawowania sakramentów. Swoją gorliwość okupił wieloletnim więzieniem. W świetle tych rozważań można przyjąć, że beatyfikacja ks. Bukowińskiego była nie tylko potwierdzeniem jego osobistej świętości, ale także zwróceniem uwagi na znaczenie działalności, którą prowadził. Także na jej pedagogiczny charakter.

\section{ABStrakt}

\section{Pedagogiczne aspekty duszpasterskiej działalności}

\section{bł. ks. Władysława Bukowińskiego}

Beatyfikacja ks. Władysława Bukowińskiego zwraca uwagę na podejmowaną przez niego działalność duszpasterską. Posiada ona wyraźny rys pedagogiczny, który wyraża się w wychowawczej trosce o wszechstronny rozwój powierzonych mu osób. Błogosławiony, dostosowując swe działania do ekstremalnych warunków życia w łagrze, a także do trudnych warunków duszpasterzowania bez kościoła, wypracował autorskie formy tej działalności. Podstawową kategorią jego pedagogii było spotkanie z drugim człowiekiem oraz towarzyszący temu spotkaniu dialog. Dzięki nim docierał do wielu osób, przekazując im prawdę o miłości Boga i ludzkiej godności. 
Pedagogia ks. Bukowińskiego posiada cechy charakteryzujące proces wychowania, zakładający afirmację ludzkiej godności, permanencję, intraakcyjność, dwustronną relację z innymi, transgresyjność i nieokreśloność. Zaangażowanie ks. Władysława napotykało na sprzeciw ze strony komunistycznych władz i wyrażało się w represjach i prześladowaniach. Niezłomna postawa błogosławionego była ważnym czynnikiem budującym jego autorytet i wpływającym na postawy innych.

\section{SŁoWA KLUCzowe}

Kazachstan, Bukowiński, pedagogia, duszpasterstwo, łagry

\section{ABstract}

\section{Pedagogical aspects of the ministry of blessed Władysław Bukowiński}

The beatification of Fr. Władysław Bukowiński draws attention to his pastoral work. It has a clear pedagogical reference, which can be observed in his educational care for the comprehensive development of the faithful. Blessed Fr. Bukowiński developed his own forms of pastoral work since he needed to adjust to the extreme conditions of life in a labor camp and ministering without a church building. The basic category of his pedagogy was the encounter with people and dialogue. In this way, he was able to reach the faithful and share with them the truth of God's love and human dignity. Bukowiński's pedagogy contains the elements of the educational process, e.g. the affirmation of human dignity, permanence, intraactivity, mutual relationships, transgression and indeterminacy. The communist authorities opposed Fr. Bukowiński's work. He was repressed and persecuted. His perseverance was a key factor which made the faithful follow him and treat him with great respect.

\section{KEYWORDS}

Kazachstan, Bukowiński, pedagogy, pastoral work, labor camp

\section{BIBLIOGRAFIA}

Beatyfikacja ks. Bukowińskiego Apostoła Kazachstanu, http://pl.radiovaticana.va/ news/2016/o9/11/beatyfikacja_ks_bukowi\%C5\%84skiego_aposto\%C5\%82a_kazachstanu/1257363 (3.10.2016).

Bukowiński W., Historia nauczycielka życia (Historia Polski pisana $w$ łagrze), red. J. Nowak, Kraków 2007.

Bukowiński W., Listy, red. J. Nowak, Kraków 2007.

Bukowiński W., Wspomnienia z Kazachstanu, Warszawa 2016. 
Bukowiński W., Wybór wspomnień i informacji dla moich przyjaciół, red. J. Nowak, Kraków 2007.

Dla moich przyjaciót. Wyjątki ze „,Wspomnieñ”, „Historii Polski” i „Listów”Stugi Bożego ks. Władysława Bukowińskiego, red. J. Nowak, Kraków 2008.

Jan Paweł II, List Juvenum patris w 10o. rocznicę śmierci św. Jana Bosko (31.01.1988).

Kunowski S., Podstawy współczesnej pedagogiki, Warszawa 1996.

Lenik D., Ze Wschodu na Zachód... Ewangeliczne drogi ks. W. Bukowińskiego. Refleksje dla cierpiących i zagubionych oraz dla zdrowych i szczęśliwych. Droga Krzyżowa, Bielsko-Biała 2007.

Łobocki M., Teoria wychowania w zarysie, Kraków 2006.

Nowak J., Apostoł Kazachstanu. Stuga Boży ks. Władysław Bukowiński (1904-1974), Kraków 2006.

Nowak J., Misjonarz Wschodu sługa Boży ks. Władysław Bukowiński, Kraków 2008. Nowak J., Najbliżsi przyjaciele ks. Władysława Bukowińskiego - ks. Bronisław Drzepecki i ks. Józef Kuczyński, Kraków 2009.

Nowak J., Nie dałem się nigdy zatruć nienawiścią... Życie ks. Władysława Bukowińskiego w świetle cnót chrześcijańskich (w perspektywie procesu beatyfikacyjnego), Kraków 2016.

Nowak J., Niezłomny Pasterz. Duszpasterstwo ks. Władysława Bukowińskiego w Kazachstanie w latach 1950-1974, Kraków 2013.

Nowak J., Świadek. Życie i działalność Sługi Bożego ks. Władysława Bukowińskiego, apostoła Kazachstanu, Kraków 2009.

Nowak J., Vianney Wschodu. Ks. Władysław Bukowiński, Kraków 2010.

Nowak M., Dialog w wychowaniu, „Pedagogia Christiana” 25 (2010), s. 85-103.

Stuga Boży ks. Władysław Bukowiński (1904-1974). Materiały z sympozjum zorganizowanego w Sanktuarium Bożego Miłosierdzia w Krakowie-Lagiewnikach 23 czerwca 2007 roku w pierwsza rocznicę rozpoczęcia procesu kanonizacyjnego, red. J. Nowak, Kraków 2007. Spotkałem człowieka. Ks. Władysław Bukowiński w pamięci wiernych i przyjaciół, cz. 1, oprac. W. J. Kowalów, Biały Dunajec-Ostróg 2001.

Spotkałem człowieka. Ks. Władysław Bukowiński w pamięci wiernych i przyjaciół, cz. 2, oprac. W. J. Kowalów, Biały Dunajec-Ostróg 2006.

Sujak E., Życie jako zadanie, Warszawa 1978.

Śliwerski B., Pedagogika ogólna. Podstawowe prawidłowości, Kraków 2012.

Śliwerski B., Współczesne teorie i nurty wychowania, Kraków 2015.

Tarnawski J., Problem chrześcijańskiej pedagogiki egzystencjalnej, „Collectanea Theologica" 44 (1974), s. 5-23.

Tchorzewski A. M. de, Wychowanie, [w:] Encyklopedia pedagogiczna XxI wieku, t. 7, red. T. Pilch, Warszawa 2008, s. 667. 